\title{
Sequence of Events Mediating the Effect of Cholera Toxin on Rat Thymocytes
}

\author{
James M. Boyle and Jerry D. Gardner \\ From the Section on Gastroenterology, Digestive Diseases Branch, National \\ Institute of Arthritis, Metabolism, and Digestive Diseases, National Institutes \\ of Health, Bethesda, Maryland 20014
}

A B S T RACT We have found that in rat thymocytes binding of $\left[{ }^{225} \mathrm{I}\right]$ choleragen is followed by cellular accumulation of cyclic $3^{\prime}, 5^{\prime}$-AMP which, in turn, is followed by stimulation of amino acid transport. Binding of cholera toxin was complete by $30 \mathrm{~min}$ and remained constant for the subsequent $150 \mathrm{~min}$. After stimulation by choleragen, cellular cyclic $3^{\prime}, 5^{\prime}$-AMP became maximal by $30 \mathrm{~min}$, after which it declined steadily so that by 90 min of incubation, cellular cyclic nucleotide levels were only $20 \%$ of those seen at $30 \mathrm{~min}$. Stimulation of amino acid transport, although detectable by $15 \mathrm{~min}$, did not become maximal until $120 \mathrm{~min}$ (by which time cellular cyclic $3^{\prime}, 5^{\prime}$-AMP had decreased by more than $80 \%$ ). We have also used this system to delineate the step at which various pharmacologic agents and hormones act to alter the sequence of events mediating the response of rat thymocytes to cholera toxin. The ability of cycloheximide to abolish choleragen-stimulated amino acid influx without reducing $\left[{ }^{225} \mathrm{I}\right]$ choleragen binding or cellular cyclic $3^{\prime}, 5^{\prime}$-AMP suggests that cyclic nucleotide stimulation of amino acid transport includes a step involving protein synthesis.

\section{INTRODUCTION}

Cholera toxin stimulates adenylate cyclase activity and tissue cyclic $3^{\prime}, 5^{\prime}$-AMP in small intestinal mucosa, leukocytes, lymphocytes, platelets, fat cells, thyroid, and liver (1-14). The particular functional alterations produced by cholera toxin in each of these tissues presumably reflect those cellular functions under the control of cyclic 3',5'-AMP (4). In contrast to other agents that act by stimulating adenylate cyclase, cholera toxin has

Dr. Boyle was a Research Associate, National Institute of Allergy and Infectious Diseases.

Received for publication 15 August 1973 and in revised form 23 October 1973. generally been found not to increase adenylate cyclase activity in broken cell preparations obtained from tissues that, when intact, respond to cholera toxin $(2,8)$. Furthermore, a substantial delay has been noted between the time at which tissue is first exposed to cholera toxin and the time at which an effect can be detected $(2,4,7$, 12). Finally, the effect of cholera toxin has been difficult or impossible to reverse after exposing tissue to cholera toxin for a period as short as a few minutes and then removing the unbound toxin by adding antiserum or by washing the tissue $(1,2)$. In an effort to begin to elucidate the basis of these characteristic features, we have studied directly the interaction of cholera toxin with intact lymphocytes obtained from rat thymus. Rat thymocytes constitute a particularly advantageous tissue because they can be obtained readily in large numbers, free of other cell types, without the use of digestive enzymes, and can be manipulated in vitro for as long as $6 \mathrm{~h}$. We have also explored the sequence of events initiated by the interaction of cholera toxin with rat thymocytes, as well as the point in this sequence at which various pharmacologic agents act to alter the effect of cholera toxin on cell function.

\section{METHODS}

Suckling Sprague-Dawley rats, 11 days old, were purchased from Taconic Farms, Inc. (Germantown, N. Y.) ; $\left[1-{ }^{14} \mathrm{C}\right]-$ $\alpha$-aminoisobutyric acid (AIB) ${ }^{1}(5.3 \mathrm{mCi} / \mathrm{mmol})$, from New England Nuclear (Boston, Mass.); [ $\left.{ }^{125} \mathrm{I}\right]$ sodium iodide (carrier-free) from Amersham/Searle Corp. (Arlington Heights, Ill.) ; chloramine-T from Eastman Kodak Co. (Rochester, N. Y. ) ; ethacrynic acid from Merck, Sharpe and Dohme, Inc. (West Point, $\mathrm{Pa}$.) ; polymyxin $\mathrm{B}$ sulfate from Burroughs Wellcome \& Co., Inc. (Tuckahoe, N. Y.) ; cycloheximide, dibutyryl cyclic $3^{\prime}, 5^{\prime}-\mathrm{AMP}$, DL-isoproterenol, L-epinephrine, and L-phenylephrine from Sigma

${ }^{1}$ Abbreviations used in this paper: AIB, $\alpha$-aminoisobutyric acid; $\mathrm{PGE}_{\mathbf{1}}$, prostaglandin $\mathrm{E}_{\mathbf{1}}$. 


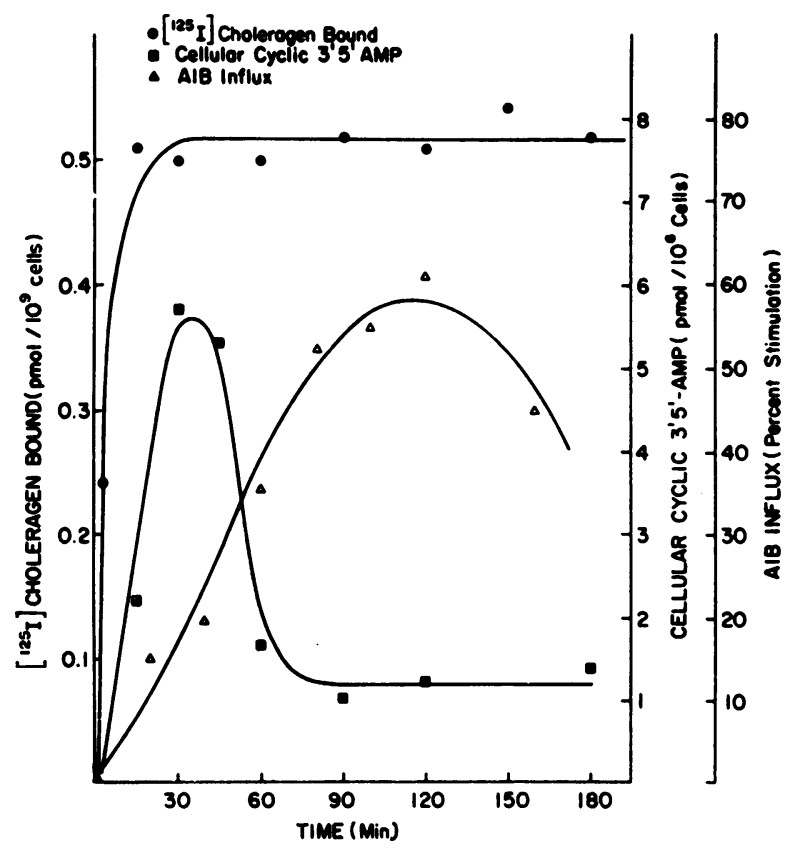

Figure 1 Time courses for binding of $\left[{ }^{125} \mathrm{I}\right]$ choleragen, cellular cyclic $3^{\prime}, 5^{\prime}-\mathrm{AMP}$, and stimulation of $\left[{ }^{14} \mathrm{C}\right] \mathrm{AIB}$ influx in rat thymocytes. Specific $\left[{ }^{125} \mathrm{I}\right]$ choleragen binding was determined in thymocytes $\left(4 \times 10^{7}\right.$ cells $\left./ \mathrm{ml}\right)$ incubated at $37^{\circ} \mathrm{C}$ with $\left[{ }^{125} \mathrm{I}\right]$ choleragen $\left(10^{-10} \mathrm{M}\right)$. Cellular cyclic $3^{\prime}, 5^{\prime}$-AMP and AIB influx were determined with thymocytes incubated with and without choleragen $\left(10^{-7} \mathrm{M}\right)$. AIB influx is expressed as the percent by which influx in choleragen-treated cells is increased above that in cells incubated without toxin. Cellular cyclic $3^{\prime}, 5^{\prime}-\mathrm{AMP}$ and AIB influx in thymocytes incubated without choleragen did not change significantly during the $3-\mathrm{h}$ incubation period. Results shown are the means of duplicate determinations and this experiment is representative of three others.

Chemical Co. (St. Louis, Mo.). All other chemicals were of the highest grade of purity commercially available.

The following were provided as gifts: choleragen, choleragenoid, and equine antiserum to choleragenoid prepared by Dr. Richard Finkelstein and distributed by the $\mathrm{Na}$ tional Institute of Allergy and Infectious Diseases; prostaglandin $E_{1}\left(P_{G E}\right)$ from Dr. John Pike of the Upjohn Co., (Kalamazoo, Mich.); and porcine insulin (25 $\mathrm{U} / \mathrm{mg})$ from Dr. Ira Goldfine.

Preparation of $\left[{ }^{125} I\right]$ choleragen. $\left[{ }^{125} \mathrm{I}\right]$ choleragen was prepared according to the technique of Hunter and Greenwood (15), with $10 \mu \mathrm{g}$ of choleragen, $2 \mathrm{mCi}$ of ${ }^{125} \mathrm{I}$, and $5 \mu \mathrm{g}$ of chloramine $\mathrm{T}$ in $110 \mu \mathrm{l}$ of $0.5 \mathrm{M}$ phosphate buffer, $\mathrm{pH} 7.5$ at $23^{\circ} \mathrm{C}$. $30 \mathrm{~s}$ after the addition of chloramine $\mathrm{T}$, $500 \mu \mathrm{g}$ of sodium metabisulfite was added. $200 \mu 1$ of a buffer containing $120 \mathrm{mM} \mathrm{NaCl}, 25 \mathrm{mM}$ Tris $\mathrm{HCl}(\mathrm{pH}$ $7.5)$, and $10 \mathrm{mg} / \mathrm{ml}$ of bovine serum albumin were then added, and $\left[{ }^{125} \mathrm{I}\right]$ choleragen was isolated by gel filtration on Sephadex G-25. The labeled choleragen had a specific activity of approximately $25 \mu \mathrm{Ci} / \mu \mathrm{g}$ and one atom of ${ }^{225} \mathrm{I}$ per molecule of choleragen.

Preparation of thymocytes. Thymocyte suspensions were prepared according to the procedure of Goldfine, Gardner, and Neville (16). Thymus glands were removed from suckling rats of either sex and were teased apart with dental forceps in $5 \mathrm{ml}$ of buffer in a plastic petri dish. The standard buffer contained $120 \mathrm{mM} \mathrm{NaCl}, 5 \mathrm{mM}$ $\mathrm{KCl}, 1 \mathrm{mM} \mathrm{CaCl}, 2.5 \mathrm{mM} \mathrm{MgCl}, 1.5 \mathrm{mM} \mathrm{NaH}_{2} \mathrm{PO}_{4}, 15$ $\mathrm{mM}$ glucose, $25 \mathrm{mM}$ Tris $\mathrm{HCl}(\mathrm{pH} 7.5)$, and $5 \mathrm{mg} / \mathrm{ml}$ bovine serum albumin. After the glands were teased apart, the cells were filtered through nylon screen and then centrifuged at $100 \mathrm{~g}$ at $4^{\circ} \mathrm{C}$ for $10 \mathrm{~min}$. The supernate was discarded and the cells were resuspended in the standard buffer. Over $95 \%$ of the cells were viable as judged by trypan blue exclusion.

$\left[{ }^{125} I\right]$ choleragen binding. Choleragen binding was determined by methods similar to those described previously for insulin binding (16). Suspensions of thymocytes (approximately $5 \times 10^{*}$ cells $/ \mathrm{ml}$ ) were incubated with $\left[{ }^{125} \mathrm{I}\right]$ choleragen (approximately $10^{-10} \mathrm{M}$ ) at $37^{\circ} \mathrm{C}$. At appropriate times $100-\mu \mathrm{l}$ samples were taken and washed three times with $300 \mu \mathrm{l}$ of iced $\left(4^{\circ} \mathrm{C}\right)$ buffer by alternate centrifugation at $10,000 \mathrm{~g}$ for $15 \mathrm{~s}$ in a Beckman Microfuge (Beckman Instruments, Inc., Spinco Div., Palo Alto, Calif.) and resuspension. The centrifuge tube and its contents were then placed in a vial for determination of radioactivity. Specific binding of $\left[{ }^{125} \mathrm{I}\right]$ choleragen was calculated as the difference between the number of counts bound with and without $10^{-6} \mathrm{M}$ nonradioactive choleragen. In all experiments sufficient $\left[{ }^{125} \mathrm{I}\right]$ choleragen was added to the incubation solution so that at most $10 \%$ of the total radioactivity was bound by the cells.

Cyclic mucleotide assay. Thymocytes (approximately 5 $\times 10^{7}$ cells $/ \mathrm{ml}$ of standard buffer) were incubated at $37^{\circ} \mathrm{C}$. At the end of the incubation period the cells were sedimented by centrifugation and the supernate was discarded. $1 \mathrm{ml}$ of $50 \%$ glacial acetic (vol/vol) was added and the tube was mixed vigorously on a Vortex (Vortec Corp., Cincinnati, Ohio) mixer. After centrifugation at $2,500 \mathrm{~g}$ for $10 \mathrm{~min}, 300-\mu \mathrm{l}$ samples of supernate were transferred to test tubes and evaporated to dryness at $80^{\circ} \mathrm{C}$. The resulting residue was resuspended in $1 \mathrm{ml}$ of $0.05 \mathrm{M}$ sodium acetate $(\mathrm{pH}$ 6.2), and samples were taken for determination of cyclic $3^{\prime}, 5^{\prime}-\mathrm{AMP}$ or cyclic $3^{\prime}, 5^{\prime}-\mathrm{GMP}$ by a modification (17) of the radioimmunoassay described by Steiner, Kipnis, Utiger, and Parker (18).

$A I B$ influx. Influx of the nonmetabolizable amino acid AIB was measured by the technique described previously (16). Thymocytes $\left(2-8 \times 10^{7}\right.$ cells $\left./ \mathrm{ml}\right)$ were incubated at $37^{\circ} \mathrm{C}$ in standard buffer containing $\left[{ }^{14} \mathrm{C}\right] \mathrm{AIB}$ (usually 30 $\mu \mathrm{M})$. At zero and $15 \mathrm{~min} 100-\mu \mathrm{l}$ samples were taken and the cells were washed three times with $300 \mu 1$ of iced $\left(4^{\circ} \mathrm{C}\right)$ buffer containing no $\left[{ }^{14} \mathrm{C}\right] \mathrm{AIB}$. Washing was accomplished by alternate centrifugation for $15 \mathrm{~s}$ at $10,000 \mathrm{~g}$ with a Beckman Microfuge, and resuspension. $100 \mu \mathrm{l}$ of $10 \%$ ( vol/vol) perchloric acid was added to the washed cells. The mixture was agitated, centrifuged at $10,000 g$ for $45 \mathrm{~s}$ and dispersed into $20 \mathrm{ml}$ of liquid scintillation solution. AIB influx was calculated from the net uptake of radioactivity during the $15-\mathrm{min}$ incubation period, ${ }^{2}$ the concentration of cells, and the specific activity of $\left[{ }^{14} \mathrm{C}\right] \mathrm{AIB}$ in the incubation solution.

\section{RESULTS}

When rat thymocytes were incubated with $\left[{ }^{125} \mathrm{I}\right]$ choleragen, the labeled toxin bound to the cell within min-

${ }^{2} \mathrm{We}$ have found that uptake of $\left[{ }^{14} \mathrm{C}\right] \mathrm{AIB}$ is a linear function of time for at least $20 \mathrm{~min} \mathrm{(16).}$ 
utes (Fig. 1). This binding was followed by cellular accumulation of cyclic $3^{\prime}, 5^{\prime}$-AMP and later, by stimulation of amino acid transport (monitored by measuring the influx of $\left.\left[{ }^{14} \mathrm{C}\right] \mathrm{AIB}\right)$. Approximately $50 \%$ of $\left[{ }^{125} \mathrm{I}\right]-$ choleragen binding occurred within 2 min. Binding was complete by $30 \mathrm{~min}$ and remained constant for the subsequent $150 \mathrm{~min}$. Cellular cyclic $3^{\prime}, 5^{\prime}$-AMP increased during the initial $30 \mathrm{~min}$, after which it declined steadily. By $90 \mathrm{~min}$ of incubation cyclic nucleotide levels were only slightly greater than those in cells incubated without choleragen. Choleragen did not alter detectably cellular levels of cyclic $3^{\prime}, 5^{\prime}$-GMP during the 180 -min incubation period $\left(0.06 \pm 0.01 \mathrm{pmol} / 10^{\circ}\right.$ cells, mean $\pm 1 \mathrm{SD}$, $n=6$ ). Amino acid transport increased more slowly and did not reach maximum levels until $120 \mathrm{~min}$, by which time cellular cyclic $3^{\prime}, 5^{\prime}$-AMP had decreased by more than $80 \%$. When the incubation temperature was reduced to $4^{\circ} \mathrm{C}$, the time-course of $\left[{ }^{125} \mathrm{I}\right]$ choleragen binding was identical to that observed at $37^{\circ} \mathrm{C}$, except that at $4^{\circ} \mathrm{C}$ the amount of tracer at the steady-state was reduced by approximately $20 \%$ (Fig. 2 ). At $4^{\circ} \mathrm{C}$ cho-

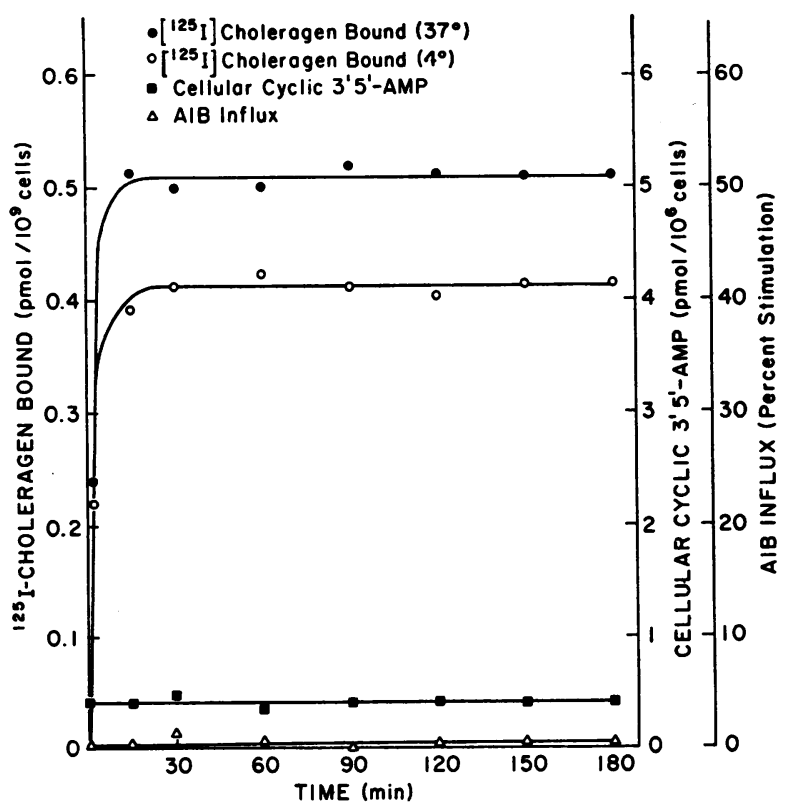

FIgURE 2 Time courses for binding of [ $\left.{ }^{125} \mathrm{I}\right]$ choleragen, cellular cyclic $3^{\prime}, 5^{\prime}-\mathrm{AMP}$, and stimulation of $\left[{ }^{14} \mathrm{C}\right] \mathrm{AIB}$ influx in rat thymocytes incubated at $4^{\circ} \mathrm{C}$. Specific binding of $\left[{ }^{125} \mathrm{I}\right]$ choleragen was determined with thymocytes $(4 \times$ $10^{\circ}$ cells $\left./ \mathrm{ml}\right)$ incubated with $\left[{ }^{125} \mathrm{I}\right]$ choleragen $\left(10^{-10} \mathrm{M}\right)$ at $4^{\circ} \mathrm{C}$ (open circles) and at $37^{\circ} \mathrm{C}$ (closed circles). Cellular cyclic $3^{\prime}, 5^{\prime}$-AMP was measured in cells incubated at $4^{\circ} \mathrm{C}$ with choleragen $\left(10^{-7} \mathrm{M}\right)$. To measure AIB influx, thymocytes were incubated at $4^{\circ} \mathrm{C}$ with and without choleragen $\left(10^{-7} \mathrm{M}\right)$. At the indicated times a sample of the cell suspension was taken and influx of $\left[{ }^{14} \mathrm{C}\right] \mathrm{AIB}$ was determined during a $10-$ min period at $37^{\circ} \mathrm{C}$. Results shown are the means of duplicate determinations and this experiment is representative of two others.

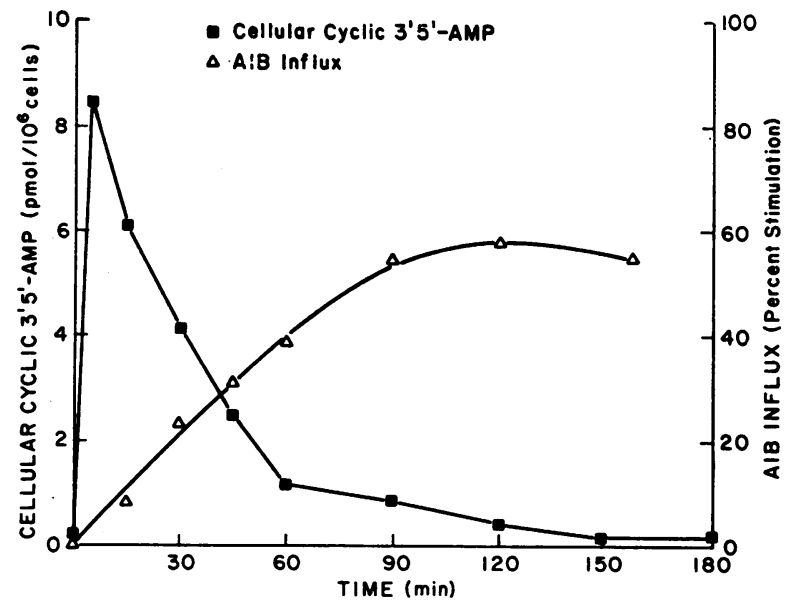

FIgURE 3 Stimulation of cellular cyclic $3^{\prime}, 5^{\prime}$-AMP and AIB influx in rat thymocytes exposed to $\mathrm{PGE}_{1}$. Cellular cyclic $3^{\prime}, 5^{\prime}$-AMP and AIB influx were determined with thymocytes incubated at $37^{\circ} \mathrm{C}$ with and without $\mathrm{PGE}_{1}\left(10^{-4}\right.$ $M)$. AIB influx is expressed as the percent by which influx in $\mathrm{PGE}_{1}$-treated cells is increased above that in cells incubated without $\mathrm{PGE}_{1}$. Cellular cyclic $3^{\prime}, 5^{\prime}-\mathrm{AMP}$ and AIB influx in thymocytes incubated without choleragen did not change significantly during the $3-\mathrm{h}$ incubation period. Results shown are the means of duplicate determinations and this experiment is representative of five others.

leragen did not stimulate cellular accumulation of cyclic $3^{\prime}, 5^{\prime}$-AMP or AIB influx. When rat thymocytes were incubated with $\mathrm{PGE}_{1}\left(10^{-4} \mathrm{M}\right)$, cellular cyclic $3^{\prime}, 5^{\prime}$ AMP increased by more than 50 -fold during the first 3 min of incubation (Fig. 3). Thereafter, cellular cyclic nucleotide levels decreased steadily and by $150 \mathrm{~min}$ of incubation were not significantly different from control

\section{TABLE I}

Absence of Effect of Cations on Binding of $\left[{ }^{125} I\right]$ Choleragen to Rat Thymocytes

\begin{tabular}{lc}
\hline \multicolumn{1}{c}{ Incubation } & $\begin{array}{c}{[1261] \text { choleragen }} \\
\text { bound }\end{array}$ \\
\hline Control & $\%$ \\
Minus sodium & $100 \pm 12$ \\
Minus potassium & $93 \pm 8$ \\
Minus calcium & $96 \pm 11$ \\
& $93 \pm 14$
\end{tabular}

Binding of $[125 \mathrm{I}]$ choleragen to thymocytes $\left(6 \times 10^{7}\right.$ cells $\left./ \mathrm{ml}\right)$ was measured after incubation for $30 \mathrm{~min}$ at $37^{\circ} \mathrm{C}$. Control values were obtained with the standard incubation solution (see Methods). When a particular cation was removed from the standard incubation solution, isosmotic choline chloride was used as replacement. Values are expressed as percent of specific [ $\left.{ }^{125} \mathrm{I}\right]$ choleragen binding observed in the standard incubation solution. Each value is the mean of three experiments \pm 1 SD. 


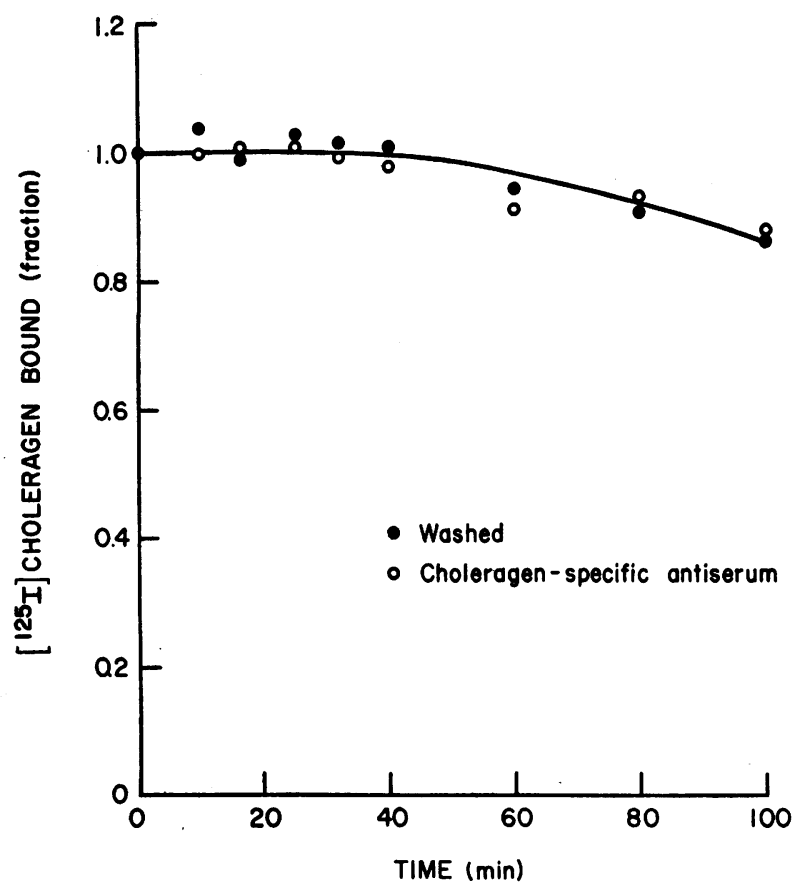

FIGURE 4 Loss of bound $\left.{ }^{120} \mathrm{I}\right]$ choleragen from rat thymocytes. Thymocytes were preincubated at $37^{\circ} \mathrm{C}$ with $\left.{ }^{125} \mathrm{I}\right]-$ choleragen $\left(10^{-10} \mathrm{M}\right)$ for $60 \mathrm{~min}$. One portion of cells was washed four times with 100 vols of iced $\left(4^{\circ} \mathrm{C}\right)$ standard buffer containing no radioactivity and resuspended in buffer at $37^{\circ} \mathrm{C}$. Choleragen-specific antiserum at a concentration sufficient to abolish the effects of $10^{-7} \mathrm{M}$ choleragen (see Table III) was added to another portion of cells. Each value is expressed as the fraction of the counts bound at the beginning of the incubation. Results shown are the means of three experiments.

values. ${ }^{3}$ The time course for AIB influx followed that for cellular cyclic $3^{\prime}, 5^{\prime}$-AMP. Stimulation of AIB influx could be detected by 15 min after addition of $P_{G E}$; however, maximal stimulation of AIB influx was not observed until $120 \mathrm{~min}$ (by which time cellular cyclic $3^{\prime}, 5^{\prime}$-AMP had decreased by more than $90 \%$ ). Binding of choleragen did not appear to be dependent on the cation composition of the incubation solution, since replacing extracellular sodium, potassium, or calcium with choline did not alter $\left[{ }^{225} \mathrm{I}\right]$ choleragen binding (Table I).

Others $(1,2,4)$ have found that after the first few minutes of incubation with choleragen, it has been impossible to reverse the toxin's effect on cell function either by adding antitoxin or by washing the tissue and

We noted that the amount of cellular cyclic $3^{\prime}, 5^{\prime}$-AMP produced in response to choleragen or to $\mathrm{PGE}_{1}$ tended to vary among different litters of rats (compare results in Figs. 1, 3, and 6, and Table II with those in Table IV). We are unable to account for the source of this variation; however, appropriate controls were performed to take this variation into account. Furthermore, each experiment was performed on at least two different litters of animals. resuspending it in toxin-free solution. We found that after incubating thymocytes with $\left[{ }^{225} \mathrm{I}\right]$ choleragen, adding choleragen-specific antiserum or washing and resuspending the cells in choleragen-free medium produced only minimal dissociation of the bound tracer (approximately $10-15 \%$ by $100 \mathrm{~min}$ ) (Fig. 4 ).

To estimate the apparent affinity of rat thymocytes for choleragen ".we tested its ability to inhibit binding of $\left[{ }^{225} \mathrm{I}\right]$ choleragen (Fig. 5). Half-maximal inhibition was observed at approximately $2 \times 10^{-8} \mathrm{M}$ choleragen and binding was inhibited completely at $10^{-8} \mathrm{M}$. Choleragenoid, a natural toxoid of choleragen, also inhibited binding of $\left[{ }^{125} \mathrm{I}\right]$ choleragen with a potency equal to that observed with choleragen. The ability of choleragen and choleragenoid to inhibit binding of $\left[{ }^{125} \mathrm{I}\right]$ choleragen to rat thymocytes was abolished by boiling $\left(100^{\circ} \mathrm{C}\right)$ either agent for $30 \mathrm{~min}$. Choleragenoid, at concentrations that produced maximal binding to rat thymocytes, did not stimulate cellular cyclic $3^{\prime}, 5^{\prime}$-AMP or amino acid transport but could inhibit the effects of choleragen (Table

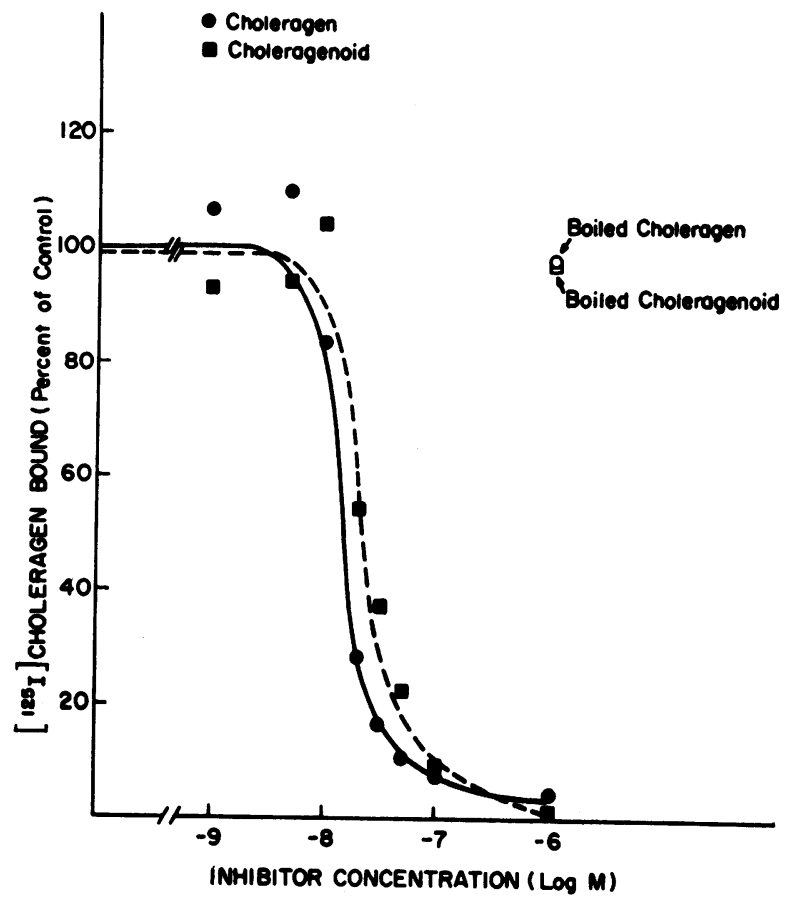

FIGURE 5 Inhibition of specific [ $\left.{ }^{126} \mathrm{I}\right]$ choleragen binding to rat thymocytes by choleragen and choleragenoid. Thymocytes $\left(1 \times 10^{7}\right.$ cells $\left./ \mathrm{ml}\right)$ were incubated at $37^{\circ} \mathrm{C}$ for 30 min with $\left[{ }^{125} \mathrm{I}\right]$ choleragen $\left(10^{-10} \mathrm{M}\right)$ and various concentrations of choleragen and choleragenoid. Values are expressed as percent of the counts bound in the absence of choleragen or choleragenoid. Results shown are the means of duplicate determinations. This experiment is representative of two others.

\footnotetext{
- The molecular weights used for choleragen and choleragenoid were 84,000 and 56,000 , respectively.
} 
II). As might be expected from its inability to inhibit binding of $\left[{ }^{20} \mathrm{I}\right]$ choleragen, boiled choleragen did not stimulate cyclic $3^{\prime}, 5^{\prime}$-AMP or AIB influx.

Fig. 6 illustrates the "dose-response" curves for the effect of choleragen on cellular accumulation of cyclic $3^{\prime}, 5^{\prime}$-AMP and on AIB influx. Stimulation of cyclic $3^{\prime}, 5^{\prime}$-AMP and of AIB influx was detectable with $10^{-8} \mathrm{M}$ choleragen and was maximal at $10^{-8} \mathrm{M}$. Choleragen iodinated with ${ }^{19} \mathrm{I}$ was equipotent with native choleragen in terms of its ability to inhibit binding of $\left[{ }^{225} \mathrm{I}\right]$ choleragen and to stimulate cellular cyclic $3^{\prime}, 5^{\prime}$-AMP and AIB influx (Table III).

Adding choleragen-specific antiserum to the thymocyte suspension just before adding $\left[{ }^{125} \mathrm{I}\right]$ choleragen abolished binding of the labeled toxin (Table IV). Antitoxin alone did not alter cellular cyclic $3^{\prime}, 5^{\prime}$-AMP or AIB influx but abolished the stimulation of these two cellular functions by choleragen.

Since $\mathrm{PGE}_{1}$ and insulin have both been shown to stimulate AIB influx in rat thymocytes $(16,19)$ we were interested to see if either of these agents altered the effects of choleragen (Table IV). Neither agent altered binding of $\left[{ }^{128} \mathrm{I}\right]$ choleragen. In agreement with previous studies (19) $\mathrm{PGE}_{1}$, but not insulin, stimulated cellular cyclic 3',5'-AMP; however, both hormones produced a significant increase in AIB influx. The value for cellular cyclic $3^{\prime}, 5^{\prime}$-AMP in thymocytes exposed to $\mathrm{PGE}_{1}$ plus choleragen was not significantly different from the sum of the values obtained with each of these agents alone, i.e., the effects of $\mathrm{PGE}_{1}$ and choleragen on cellular cyclic $3^{\prime}, 5^{\prime}$-AMP were additive. The value for AIB influx in thymocytyes exposed to $\mathrm{PGE}_{1}$ plus choleragen was the same as that obtained with either agent alone. Insulin did not alter the effect of choleragen on cellular cyclic $3^{\prime}, 5^{\prime}$-AMP. The value for AIB influx with choleragen plus insulin was not significantly different from the

TABLE II

Effect of Choleragen and Choleragenoid on Cellular Cyclic $3^{\prime}, 5^{\prime}-A M P$ and $A I B$ Influx in Rat Thymocytes

\begin{tabular}{lcc}
\hline & $\begin{array}{c}\text { Cellular cyclic } \\
3^{\prime}, 5^{\prime} \text {-AMP }\end{array}$ & $\begin{array}{c}\text { AIB } \\
\text { influx }\end{array}$ \\
\hline & pmol/10 cells & \% control \\
Control & $0.13 \pm 0.06$ & $100 \pm 3$ \\
Choleragen $\left(10^{-8} \mathrm{M}\right)$ & $7.0 \pm 0.38$ & $141 \pm 6$ \\
Choleragenoid $\left(10^{-7} \mathrm{M}\right)$ & $0.12 \pm 0.04$ & $102 \pm 7$ \\
Choleragen $\left(10^{-8} \mathrm{M}\right)$ & $1.9 \pm 0.30$ & $128 \pm 5$ \\
$\quad+$ choleragenoid $\left(10^{-7} \mathrm{M}\right)$ & & \\
Boiled choleragen $\left(10^{-6} \mathrm{M}\right)$ & $0.11 \pm 0.06$ & $107 \pm 6$ \\
\hline
\end{tabular}

Thymocytes $\left(7 \times 10^{7}\right.$ cells $\left./ \mathrm{ml}\right)$ were incubated at $37^{\circ} \mathrm{C}$ with the agents shown above. Cellular cyclic $3^{\prime}, 5^{\prime}$-AMP and influx of $\left[{ }^{14} \mathrm{C}\right] \mathrm{AIB}$ were determined at 30 and $120 \mathrm{~min}$, respectively. Results are the mean of at least three determinations \pm 1 SD.
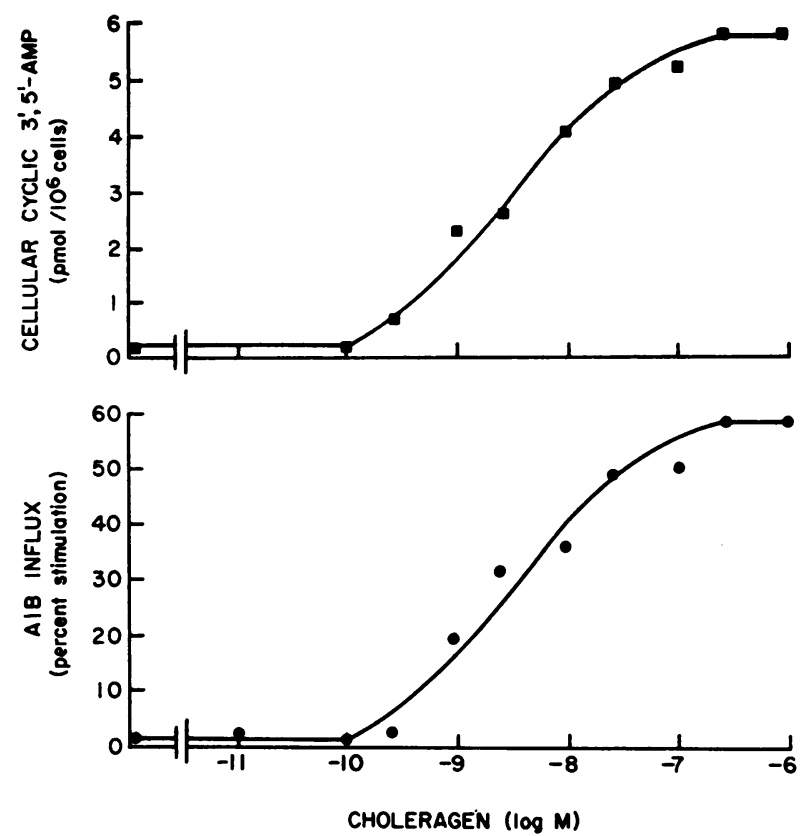

FiguRe 6 Effect of choleragen on cellular cyclic $3^{\prime}, 5^{\prime}$-AMP and AIB influx in rat thymocytes. Thymocytes $\left(3 \times 10^{7}\right.$ cells $/ \mathrm{ml}$ ) were incubated at $37^{\circ} \mathrm{C}$ with the indicated concentrations of choleragen. Cyclic $3^{\prime}, 5^{\prime}-\mathrm{AMP}$ and $\left[{ }^{14} \mathrm{C}\right] \mathrm{AIB}$ influx were determined at 30 and $120 \mathrm{~min}$, respectively. AIB influx is expressed as the percent by which influx in choleragen-treated cells increased above that in cells incubated without toxin. Results are the mean of four separate experiments.

sum of the values obtained with each of these agents alone, i.e., the effects of insulin and choleragen on AIB influx were additive.

TABLE III

Effect of Iodinated Choleragen on $[125 I]$ Choleragen Binding, Cellular Cyclic $3^{\prime}, 5^{\prime}-A M P$, and $A I B$ Influx in Rat Thymocytes

\begin{tabular}{|c|c|c|c|}
\hline Agent added & $\begin{array}{c}{[125 I] \text { choleragen }} \\
\text { bound }\end{array}$ & $\begin{array}{c}\text { Cellular } \\
\text { cyclic } \\
\text { 3',5'-AMP }^{\prime} \text {-AMP }\end{array}$ & $\begin{array}{l}\text { AIB } \\
\text { influx }\end{array}$ \\
\hline & $\%$ & $\mathrm{pmol} / 10^{\circ}$ cells & \\
\hline None & $100 \pm 11$ & $0.15 \pm 0.03$ & $1.00 \pm 9$ \\
\hline Choleragen $10^{-9} \mathrm{M}$ & $97 \pm 9$ & $1.8 \pm 0.3$ & $1.18 \pm 5$ \\
\hline $10^{-8} \mathrm{M}$ & $81 \pm 5$ & $3.6 \pm 0.2$ & $1.34 \pm 12$ \\
\hline $5 \times 10^{-8} \mathrm{M}$ & $18 \pm 4$ & $4.6 \pm 0.5$ & $1.45 \pm 7$ \\
\hline $10^{-7} \mathrm{M}$ & $8 \pm 2$ & $5.0 \pm 0.4$ & $1.54 \pm 8$ \\
\hline$\left[{ }^{127} \mathrm{I}\right]$ choleragen $10^{-9} \mathrm{M}$ & $101 \pm 11$ & $2.1 \pm 0.2$ & $1.20 \pm 6$ \\
\hline $10^{-8} \mathrm{M}$ & $78 \pm 6$ & $3.8 \pm 0.4$ & $1.37 \pm 4$ \\
\hline $5 \times 10^{-8} \mathrm{M}$ & $16 \pm 3$ & $4.4 \pm 0.5$ & $1.43 \pm 9$ \\
\hline $10^{-7} \mathrm{M}$ & $7 \pm 1$ & $6.3 \pm 0.5$ & $1.52 \pm 11$ \\
\hline
\end{tabular}

Thymocytes $\left(6 \times 10^{7} \mathrm{cells} / \mathrm{ml}\right)$ were incubated at $37^{\circ} \mathrm{C}$ with the agents indicated. [125I]choleragen binding and cellular cyclic $3^{\prime}, 5^{\prime}$-AMP were measured at $30 \mathrm{~min}$. [ $\left.{ }^{14} \mathrm{C}\right] \mathrm{AIB}$ influx was determined at $120 \mathrm{~min}$. Each result is the mean of four experiments $\pm 1 \mathrm{SD}$. [127I]choleragen was prepared by the same technique that was used to prepare [125I]choleragen except that [127I]sodium iodide was used instead of [125I]sodium iodide (see Methods). 
TABLE IV

Effect of Various Agents on $\left[{ }^{125} I\right]$ Choleragen Binding, Cellular Cyclic $3^{\prime}, 5^{\prime}-A M P$, and AIB Influx in Rat Thymocytes

\begin{tabular}{|c|c|c|c|c|c|}
\hline \multirow[b]{2}{*}{ Agent added } & \multirow[b]{2}{*}{$\begin{array}{c}{[125 I] \text { choleragen }} \\
\text { binding }\end{array}$} & \multicolumn{2}{|c|}{$\begin{array}{l}\text { Cellular cyclic } \\
3^{\prime}, 5^{\prime} \text {-AMP }\end{array}$} & \multicolumn{2}{|c|}{ AIB influx } \\
\hline & & Control & $\begin{array}{c}+ \text { Choleragen } \\
10^{-7} \mathrm{M}\end{array}$ & Control & $\begin{array}{c}+ \text { Choleragen } \\
10^{-7} \mathrm{M}\end{array}$ \\
\hline & $\%$ & \multicolumn{2}{|c|}{ pmol/106 cells } & \multicolumn{2}{|c|}{$\%$} \\
\hline None & $100 \pm 8^{*}$ & $0.19 \pm 0.06$ & $12.7 \pm 3.1$ & $100 \pm 7 \ddagger$ & $140 \pm 8$ \\
\hline Antitoxin & $3 \pm 4$ & $0.22 \pm 0.07$ & $0.23 \pm 0.06$ & $98 \pm 6$ & $101 \pm 9$ \\
\hline $\mathrm{PGE}_{1}\left(10^{-4} \mathrm{M}\right)$ & $94 \pm 9$ & $24.9 \pm 2.1$ & $39.3 \pm 5.2$ & $153 \pm 8$ & $148 \pm 7$ \\
\hline Insulin $\left(3 \times 10^{-6} \mathrm{M}\right)$ & $102 \pm 7$ & $0.13 \pm 0.08$ & $13.5 \pm 1.8$ & $151 \pm 9$ & $198 \pm 17$ \\
\hline Theophylline $\left(3 \times 10^{-3} \mathrm{M}\right)$ & $97 \pm 8$ & $0.44 \pm 0.07$ & $18.1 \pm 2.3$ & $163 \pm 11$ & $151 \pm 9$ \\
\hline Ethacrynic acid $\left(2.5 \times 10^{-4} \mathrm{M}\right)$ & $100 \pm 10$ & $0.05 \pm 0.03$ & $0.10 \pm 0.04$ & $28 \pm 4$ & $30 \pm 6$ \\
\hline Cycloheximide $\left(10^{-4} \mathrm{M}\right)$ & $95 \pm 7$ & $0.25 \pm 0.09$ & $17.6 \pm 2.3$ & $59 \pm 2$ & $63 \pm 4$ \\
\hline Polymyxin $(1 \mathrm{mg} / \mathrm{ml})$ & $168 \pm 13$ & $0.31 \pm 0.08$ & $10.2 \pm 2.8$ & $38 \pm 2$ & $38 \pm 4$ \\
\hline Isoproterenol $\left(10^{-5} \mathrm{M}\right)$ & $103 \pm 7$ & $0.24 \pm 0.06$ & $10.6 \pm 3.0$ & $97 \pm 9$ & $146 \pm 7$ \\
\hline Phenylephrine $\left(10^{-5} \mathrm{M}\right)$ & $97 \pm 10$ & $0.20 \pm 0.05$ & $13.2 \pm 3.1$ & $105 \pm 11$ & $147 \pm 8$ \\
\hline
\end{tabular}

* Results are expressed as percent of the value in the standard buffer.

$\ddagger$ Results are expressed as percent of control value in the standard buffer. Each value is the mean of five determinations $\pm 1 \mathrm{SD}$.

$\left[{ }^{125} \mathrm{I}\right]$ Choleragen binding and cellular cyclic $3^{\prime}, 5^{\prime}$-AMP were measured at $30 \mathrm{~min}$. [ $\left.{ }^{14} \mathrm{C}\right] \mathrm{AIB}$ influx was determined at $120 \mathrm{~min}$.

Theophylline, an inhibitor of cyclic nucleotide phosphodiesterase $(20)$, did not alter binding of $\left[{ }^{125} \mathrm{I}\right]$ choleragen to thymocytes, produced a small but significant increase in cellular cyclic $3^{\prime}, 5^{\prime}-\mathrm{AMP}$, and potentiated the stimulation of cyclic nucleotide produced by choleragen. Although theophylline produced only a small increase in cellular cyclic $3^{\prime}, 5^{\prime}$-AMP, it stimulated AIB influx to levels similar to those obtained with choleragen, $\mathrm{PGE}_{1}$, or insulin. The value for AIB influx with choleragen plus theophylline was the same as that obtained with either agent alone. Since phosphodiesterase(s) inhibited by theophylline also hydrolyzes cyclic $3^{\prime}, 5^{\prime}-G M P$, it seemed possible that the stimulation of AIB influx produced by theophylline alone might reflect increased levels of cellular cyclic $3^{\prime}, 5^{\prime}$-GMP. However, we detected no effect of theophylline, choleragen, $\mathrm{PGE}_{1}$, or insulin on cellular levels of cyclic $3^{\prime}, 5^{\prime}$-GMP in rat thymocytes (results not shown).

Several agents have been found to alter the effects of cholera toxin in vitro and in vivo; however, the precise step at which these agents modify the action of cholera toxin has not been elucidated. Ethacrynic acid, a diuretic agent that inhibits the effects of cholera toxin on salt and water transport in the gut $(21,22)$ and on glycerol production in fat cells (5), did not alter binding of $\left[{ }^{125} \mathrm{I}\right]$ choleragen to rat thymocytes. Ethacrynic acid reduced cellular cyclic $3^{\prime}, 5^{\prime}$-AMP and AIB influx and abolished the effect of choleragen on these two functions.

Cycloheximide, an inhibitor of protein synthesis that inhibits choleragen-stimulated intestinal secretion (2325 ) and edema in the rat footpad (26), did not alter binding of $\left[{ }^{125} \mathrm{I}\right]$ choleragen to thymocytes, and did not alter cellular levels of cyclic $3^{\prime}, 5^{\prime}$-AMP, but increased by $50 \%$ cyclic nucleotide levels produced by choleragen. Cycloheximide reduced control AIB influx by $40 \%$ and abolished choleragen-stimulated AIB influx. In cells preincubated for $60 \mathrm{~min}$ with cycloheximide, the time course for $\left[{ }^{125} I\right]$ choleragen binding was identical to that depicted in Fig. 1. The curve describing the time course for choleragen-stimulated cellular cyclic $3^{\prime}, 5^{\prime}$-AMP had the same general shape as that illustrated in Fig. 1 (although the values for cyclic $3^{\prime}, 5^{\prime}$-AMP were generally greater than those seen with choleragen alone); however, no increase in AIB influx was observed during the 3-h incubation period.

Polymyxin, an antibacterial agent with detergent properties that can inhibit the effect of choleragen on intestinal mucosa (27), increased binding of $\left[{ }^{125} \mathrm{I}\right]$ choleragen to thymocytes by $70 \%$. This agent did not alter control or choleragen-stimulated cellular cyclic $3^{\prime}, 5^{\prime}$ AMP, but reduced control AIB influx by $70 \%$ and abolished the effect of choleragen on amino acid transport.

Katz and Greenough (28) have reported an interaction between epinephrine and cholera toxin in their stimulation of lipolysis in fat cells. In rat thymocytes neither the $\beta$-adrenergic catecholamine isoproterenol nor the $\alpha$-adrenergic agent phenylephrine altered [ $\left.{ }^{25} \mathrm{I}\right]$ - 
choleragen binding, cellular cyclic $3^{\prime}, 5^{\prime}$-AMP, AIB influx, or the effect of choleragen on cyclic nucleotide levels or amino acid transport (Table IV).

\section{DISCUSSION}

The present results demonstrate directly that biologically active $\left[{ }^{125} \mathrm{I}\right]$ choleragen binds specifically to intact rat thymocytes in vitro and that binding is followed by a rise in cellular cyclic $3^{\prime}, 5^{\prime}$-AMP that, in turn, is followed by stimulation of amino acid influx. Peterson, LoSpalluto, and Finkelstein (29) found that after exposing intestinal mucosa to choleragen, the toxin could be localized to the intestinal mucosa with immunohistochemical and autoradiographic techniques. Cholera toxin can also bind to intact sheep erythrocytes, since toxintreated cells agglutinate on exposure to cholera toxinspecific antiserum $(30)$. We have also found that $\left[{ }^{125} \mathrm{I}\right]-$ choleragen binds to human erythrocytes and to turkey erythrocytes; however, adding $10^{-7} \mathrm{M}$ nonradioactive choleragen reduced binding by only $20 \%$, indicating that the apparent affinity with which choleragen binds to these cells is lower than that observed in rat thymocytes, or that the binding sites are so abundant that they cannot be "saturated" at $10^{-7} \mathrm{M}$ choleragen. Furthermore, human erythrocytes contain little or no adenylate cyclase activity, no detectable cyclic 3',5'-AMP (31), and do not respond to choleragen with changes in adenylate cyclase activity, sodium transport, or amino acid transport. Choleragen $\left(10^{-7} \mathrm{M}\right)$ also failed to stimulate adenylate cyclase or sodium transport in turkey erythrocytes, a tissue in which activation of adenylate cyclase produces a fourfold increase in sodium transport (32). Thus, binding of choleragen to a particular tissue does not necessarily indicate that choleragen produces a functional alteration in that same tissue. Instead, evidence that choleragen binding mediates the alteration in cell function requires demonstration of a correlation between binding of choleragen and the choleragen-induced alteration of cell function.

The present studies also demonstrate that choleragen, once bound to the cell, dissociates very slowly, and confirm the previous conclusions of others based on studies of the effect of cholera toxin on cell function $(1,2,4)$. The slow rate of dissociation of $\left[{ }^{25} \mathrm{I}\right]$ choleragen from the cells after addition of choleragen-specific antiserum cannot be attributed to an inability of the antibodies to bind cholera toxin, since antiserum could completely block binding of $\left[{ }^{125} \mathrm{I}\right]$ choleragen by rat thymocytes (Table IV).

There appeared to be a discrepancy between the potency with which choleragen inhibited binding of $\left[{ }^{125} \mathrm{I}\right]$ choleragen to thymocytes and the potency with which the toxin stimulated cellular accumulation of cyclic $3^{\prime}, 5^{\prime}-$ AMP and influx of AIB. Effects of the toxin on cyclic nucleotide levels and on amino acid transport could be detected readily with $10^{-8} \mathrm{M}$ choleragen; however, no significant reduction of $\left[{ }^{125} \mathrm{I}\right]$ choleragen binding could be detected until $10^{-8} \mathrm{M}$. Maximal effects on all three functions were detected at $10^{-6} \mathrm{M}$ choleragen. These results may be caused by the existence of two classes of choleragen-binding sites, each associated with an alteration of cellular function, but the class of sites with higher affinity for choleragen cannot be detected by measuring inhibition of $\left[{ }^{125} \mathrm{I}\right]$ choleragen binding, because these sites are much smaller in number than the sites with a lower affinity for choleragen. Alternatively, there may be two classes of choleragen-binding sites but the procedure used to prepare $\left[{ }^{125} \mathrm{I}\right]$ choleragen may alter the molecule so that it interacts only with the class of sites with low affinity for choleragen. This possibility, however, seems unlikely since choleragen iodinated with ${ }^{127} \mathrm{I}$ was equipotent with native choleragen, and both agents stimulated cellular cyclic $3^{\prime}, 5^{\prime}$-AMP and AIB influx at $10^{-8} \mathrm{M}$ (Table III). Finally, these results may reflect a type of "negative cooperation" between the choleragen-binding sites. That is, binding of a molecule at one site may produce an alteration in cell function (i.e., increase cellular cyclic $3^{\prime}, 5^{\prime}$-AMP) and may also reduce the affinity of one or more other binding sites for choleragen.

Our findings that choleragenoid can inhibit binding of $\left[{ }^{125} \mathrm{I}\right]$ choleragen with the same potency as choleragen and that the toxoid can inhibit choleragen-stimulated cellular cyclic $3^{\prime}, 5^{\prime}$-AMP and amino acid influx suggest that choleragenoid binds to the same cellular sites as does choleragen. Furthermore, our finding that choleragenoid binds to the cell but does not stimulate cyclic $3^{\prime}, 5^{\prime}$-AMP or amino acid transport indicates that that portion of the choleragen molecule that binds to the cell (and which is also present in the choleragenoid molecule) is different from that portion that stimulates adenylate cyclase (not present in choleragenoid). In a similar vein Finkelstein, LaRue, and LoSpalluto (33) have speculated that the biologically active portion of the choleragen molecule is a 28,000 mol-wt moiety that is not present in the choleragenoid molecule. The inability of choleragenoid to alter cell function also implies that binding of choleragen to the cell, although necessary, is not sufficient to initiate the subsequent cellular effects. That is, the choleragen binding site(s) is functionally distinct from the site at which the toxin acts to stimulate adenylate cyclase. A similar distinction between binding sites and adenylate cyclase activation sites has been made for other agents that act by stimulating adenylate cyclase (34-36).

In contrast to its effect on intestinal mucosa $(10,11)$, choleragen produced only minimal changes in sodium and potassium transport in rat thymocytes. This is probably because cation transport in rat thymocytes is not under 


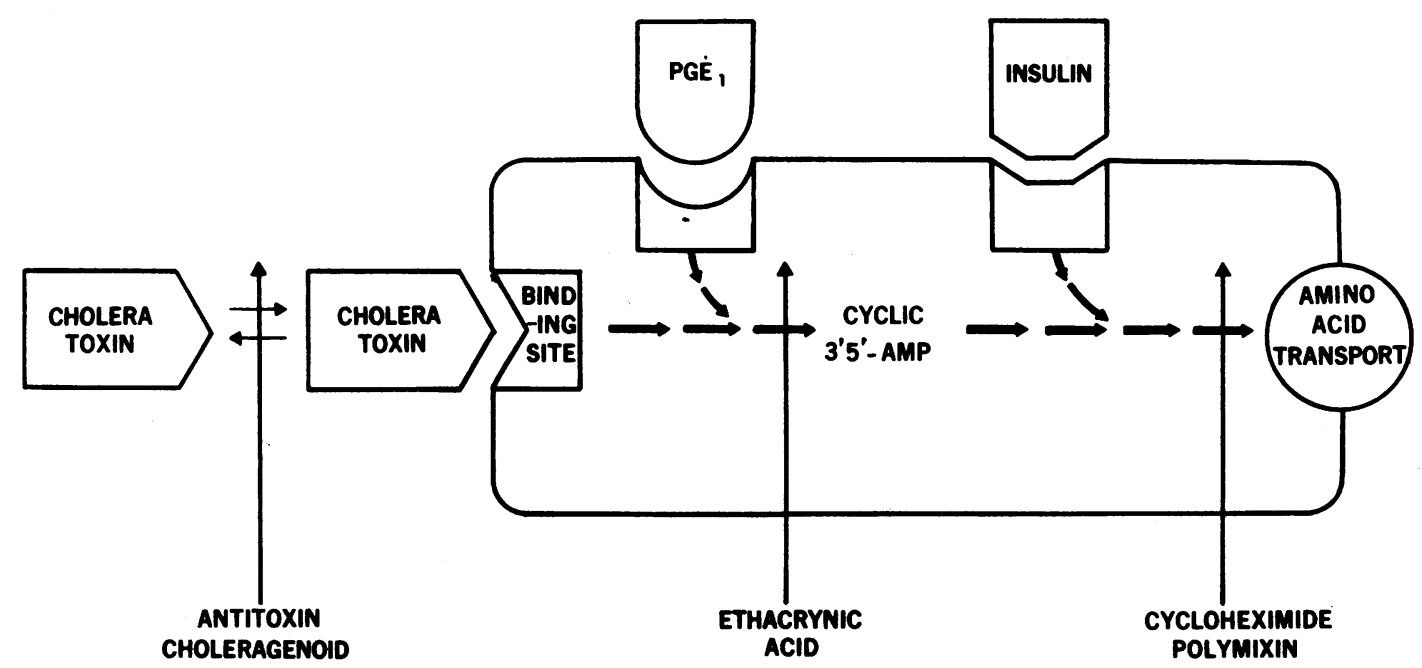

FIGURE 7 Sequence of events mediating choleragen stimulation of amino acid transport in rat thymocytes. Initially the choleragen molecule interacts reversibly with its specific cellular binding site. This interaction is followed by stimulation of adenylate cyclase, which increases cellular cyclic $3^{\prime}, 5^{\prime}-\mathrm{AMP}$. The cyclic nucleotide then through a series of presently unknown steps stimulates amino acid transport. The step at which a particular agent acts to inhibit this sequence is indicated by a vertical arrow. The hormones $\mathrm{PGE}_{1}$ and insulin can also stimulate amino acid transport by activity at the steps indicated.

the control of cyclic $3^{\prime}, 5^{\prime}-\mathrm{AMP}$, since the particular functional property affected by choleragen appears to be tissue-specific and to depend on which cell function is coupled to the adenylate cyclase-cyclic $3^{\prime}, 5^{\prime}$-AMP system (4).

We found that in contrast to sustained binding of choleragen, cellular cyclic $3^{\prime}, 5^{\prime}$-AMP increased, became maximal at approximately $30 \mathrm{~min}$, and then decreased by approximately $80 \%$ during the subsequent $60 \mathrm{~min}$. A similar pattern was observed with $\mathrm{PGE}_{1}$, although the rise in cellular cyclic $3^{\prime}, 5^{\prime}$-AMP was more rapid than that seen with choleragen. We cannot specify whether this phenomenon reflects a primary change in the rate of generation of cyclic nucleotide or a change in its rate of disposition, and additional experiments are obviously necessary to elucidate the basis of this phenomenon.

There was a substantial delay between cellular cyclic $3^{\prime}, 5^{\prime}$-AMP accumulation and stimulation of amino acid transport. After $30 \mathrm{~min}$ of incubation with choleragen, cellular levels of cyclic $3^{\prime}, 5^{\prime}$-AMP were maximal while the increase in AIB influx was only $25 \%$ of that observed at $120 \mathrm{~min}$ (by which time cyclic $3^{\prime}, 5^{\prime}$-AMP had decreased by $80 \%$ ). A similar phenomenon was observed after stimulation by $\mathrm{PGE}_{1}$, indicating that this relation between cellular cyclic $3^{\prime}, 5^{\prime}$-AMP and AIB influx is not peculiar to choleragen but instead is a property of the rat thymocyte.

Cycloheximide, an inhibitor of protein synthesis, did not alter $\left[{ }^{255} \mathrm{I}\right]$ choleragen binding or the time course of cellular cyclic $3^{\prime}, 5^{\prime}$-AMP accumulation, but abolished choleragen-stimulated AIB influx. Thus, the mechanism through which cyclic $3^{\prime}, 5^{\prime}$-AMP stimulates AIB influx may involve protein synthesis and this phenomenon may be the basis for the 90-min delay between maximal cyclic $3^{\prime}, 5^{\prime}$-AMP accumulation and maximal stimulation of amino acid transport. There is also a delay between binding of insulin to thymocytes and stimulation of amino acid transport (via a mechanism not involving cyclic $3^{\prime}, 5^{\prime}$-AMP [19]) and the effect of insulin is abolished by cycloheximide (16). In human leukocytes treated with cholera toxin there is no delay between accumulation of cyclic $3^{\prime}, 5^{\prime}$-AMP and inhibition of histamine release (1) and cycloheximide does not alter the effect of choleragen on either of these functions (2). Kimberg, Field, Gershon, Schooley, and Henderson (37) have recently reported that in intestinal mucosa cycloheximide does not alter basal ion transport or cholera toxin stimulation of adenylate cyclase and cyclic $3^{\prime}, 5^{\prime}$-AMP, but does inhibit the effect of the toxin on intestinal ion transport. Our finding, that cycloheximide reduces basal AIB transport in rat thymocytes, raises the possibility that protein synthesis is an integral part of the amino acid transport mechanism and that cyclic $3^{\prime}, 5^{\prime}$-AMP (as well as insulin) may act not by stimulating protein synthesis directly but instead by stimulating a system whose normal operation requires protein synthesis. Thus, when protein synthesis is inhibited, the transport system is inhibited and is refractory to stimulation by cyclic $3^{\prime}, 5^{\prime}$-AMP or insulin. Fi- 
nally, in plants (38) and bacteria (39) cycloheximide can alter other cellular metabolic processes besides protein synthesis; therefore, if similar effects occur in rat thymocytes, cycloheximide inhibition of amino acid transport may reflect alterations in cellular processes other than protein synthesis.

Two experimental observations indicate that there may not be a quantitative relation between total cellular cyclic $3^{\prime}, 5^{\prime}$-AMP and stimulation of AIB influx. In the presence of choleragenoid, choleragen-stimulated cellular cyclic $3^{\prime}, 5^{\prime}$-AMP was reduced by $70 \%$ but AIB influx was decreased by only $30 \%$ (Table II). It may be that in reponse to choleragen much more cyclic $3^{\prime}, 5^{\prime}-$ AMP is produced than is necessary for maximal stimulation of AIB influx. This phenomenon has been observed for other cyclic $3^{\prime}, 5^{\prime}$-AMP-stimulated functions in other tissues $(20,32)$ and our results obtained with $\mathrm{PGE}_{\mathbf{1}}$ and choleragen (Table IV) indicate that cellular cyclic $3^{\prime}, 5^{\prime}$-AMP levels can be increased without a further increase in AIB influx. Alternatively, cyclic $3^{\prime}, 5^{\prime}-$ AMP may be compartmentalized within the cell, and only changes within a particular subcellular compartment produce changes in amino acid transport. This possibility is supported by results obtained with theophylline (Table IV), which produced only a small increase in total cellular cyclic $3^{\prime}, 5^{\prime}$-AMP but stimulated AIB influx to the same levels seen with choleragen or PGE. Bourne, Lehrer, Lichtenstein, Weissmann, Zurier (2) observed an analogous effect of theophylline in human leukocytes, but concluded that theophylline might produce effects in leukocytes as it may in other tissues $(20,40)$ through a mechanism not involving cyclic $3^{\prime}, 5^{\prime}-$ AMP. The effects which we have observed with theophylline obviously do not exclude this possibility.

Several pharmacologic agents have been reported to alter the effect of choleragen on various tissues; however, the precise step at which these agents act has not been clearly delineated. Fig. 7 illustrates our conceptualization of the sequence of events involved in the mechanism of action of cholera toxin in rat thymocytes and the particular step in this sequence at which various pharmacologic agents may act to alter the response to choleragen. We have also depicted for comparison where $\mathrm{PGE}_{1}$ and insulin act in this sequence. Choleragenoid and choleragen-specific antiserum act to prevent the interaction of choleragen with specific cellular binding sites (probably located on the plasma membrane). The diuretic agent ethacrynic acid does not alter choleragen binding but reduces cellular levels of cyclic $3^{\prime}, 5^{\prime}$-AMP and abolishes the stimulation of cyclic nucleotide levels by choleragen. Although in Fig. 7 we have indicated that ethacrynic acid inhibits synthesis of cyclic $3^{\prime}, 5^{\prime}$-AMP, this is an unproved hypothesis and it is equally likely that ethacrynic acid stimulates degradation or disposition of cellular cyclic nucleotide. Polymyxin, an anti- bacterial agent with detergent properties, and cycloheximide act at some step after the accumulation of cyclic 3',5'-AMP to inhibit the stimulation of amino acid transport. PGE 1 can also stimulate AIB influx in rat thymocytes by stimulating adenylate cyclase and increasing cellular cyclic $3^{\prime}, 5^{\prime}$-AMP. Additive effects of $\mathrm{PGE}_{1}$ and choleragen were observed for stimulation of cellular cyclic 3',5'-AMP but not for stimulation if AIB transport. Insulin stimulates AIB influx by acting through a mechanism not involving cyclic $3^{\prime}, 5^{\prime}$-AMP (19). Insulin did not alter the effect of choleragen on cyclic $3^{\prime}, 5^{\prime}$-AMP and the stimulation of AIB transport by insulin added to that produced by choleragen.

Addendum. Since this paper was submitted for publication, Cuatrecasas (41-44) has reported that cholera toxin binds specifically to isolated fat cells (and to liver membranes) from the rat and that this binding correlates with cholera toxin-stimulated lipolysis. Choleragenoid inhibited binding of $\left[{ }^{125} \mathrm{I}\right]$ cholera toxin to liver membranes and did not stimulate lipolysis in fat cells, but blocked the stimulation of lipolysis by cholera toxin.

\section{REFER ENCES}

1. Lichtenstein, L. M., C. S. Henney, H. R. Bourne, and W. B. Greenough, III. 1973. Effects of cholera toxin on in vitro models of immediate and delayed hypersensitivity. Further evidence for the role of cyclic adenosine 3',5'-monophosphate. J. Clin. Invest. 52: 691.

2. Bourne, H. R., R. I. Lehrer, L. M. Lichtenstein, G. Weissmann, and R. Zurier. 1973. Effects of cholera enterotoxin on adenosine $3^{\prime}, 5^{\prime}$-monophosphate and neutrophil function. Comparison with other compounds which stimulate leukocyte adenyl cyclase. J. Clin. Invest. $52: 698$.

3. Zieve, P. D., N. F. Pierce, and W. B. Greenough, III. 1970. Stimulation of glycogenolysis by purified cholera enterotoxin in disrupted cells. Clin. Res. 18: 690.

4. Pierce, N. F., W. B. Greenough, III, and C. C. J. Carpenter, Jr. 1971. Vibrio cholerae enterotoxin and its mode of action. Bacteriol. Rev. 35: 1.

5. Vaughan, M., N. F. Pierce, and W. B. Greenough, III. 1970. Stimulation of glycerol production in fat cells by cholera toxin. Nature (Lond.). 226: 658.

6. Schafer, D. E., W. D. Lust, B. Sircar, and N. D. Goldberg. 1970. Elevated concentration of adenosine $3^{\prime}, 5^{\prime}$-cyclic monophosphate in intestinal mucosa after treatment with cholera toxin. Proc. Natl. Acad. Sci. U.S.A. $67: 851$.

7. Sharp, G. W. G., and S. Hynie. 1971. Stimulation of intestinal adenyl cyclase by cholera toxin. Nature (Lond.). $229: 266$.

8. Kimberg, D. V., M. Field, J. Johnson, A. Henderson, and E. Gershon. 1971. Stimulation of intestinal mucosal adenyl cyclase by cholera enterotoxin and prostaglandins. J. Clin. Invest. 50: 1218.

9. Chen, L. C., J. E. Rohde, and G. W. G. Sharp. 1971. Intestinal adenyl-cyclase activity in human cholera. Lancet. 1 : 939.

10. Pierce, N. F., C. C. J. Carpenter, Jr., H. L. Elliott, and W. B. Greenough, III. 1971. Effect of prostaglandins, theophylline, and cholera exotoxin upon trans- 
mucosal water and electrolyte movement in the canine jejunum. Gastroenterology. $60: 22$.

11. Field, M., D. Fromm, Q. Al-Awqati, and W. B. Greenough, III. 1972. Effect of cholera enterotoxin on ion transport across isolated ileal mucosa. J. Clin. Invest. $51: 796$.

12. Parkinson, D. K., H. Ebel, D. R. DiBona, and G. W. G. Sharp. 1972. Localization of the action of cholera toxin on adenyl cyclase in mucosal epithelial cells of rabbit intestine. J. Clin. Invest. 51: 2292.

13. Guerrant, R. L., L. C. Chen, and G. W. G. Sharp. 1972. Intestinal adenyl-cyclase activity in canine cholera: correlation with fluid accumulation. J. Infect. Dis. $125: 377$.

14. Chen, L. C., J. E. Rohde, and G. W. G. Sharp. 1972. Properties of adenyl cyclase from human jejunal mucosa during naturally acquired cholera and convalescence. J. Clin. Invest. $51: 731$.

15. Hunter, W. M., and F. C. Greenwood. 1962. Preparation of iodine-131 labelled human growth hormone of high specific activity. Nature (I ond.). 194: 495.

16. Goldfine, I. D., J. D. Gardner, and D. M. Neville, Jr. 1972. Insulin action in isolated rat thymocytes. I. Binding of ${ }^{125} \mathrm{I}$-insulin and stimulation of $\alpha$-aminoisobutyric acid transport. J. Biol. Chem. 247: 6919.

17. Desbuquois, B., and G. D. Aurbach. 1971. Use of polyethylene glycol to separate free and antibody-bound peptide hormones in radioimmunoassays. J. Clin. Endocrinol. Mctab. $33: 732$

18. Steiner, A. L., D. M. Kipnis, R. Utiger, and C. Parker. 1969. Radioimmunoassay for the measurement of adenosine-3',5'-cyclic phosphate. Proc. Natl. Acad. Sci. U. S. A. $64: 367$.

19. Goldfine, I. D., and P. Sherline. 1972. Insulin action in isolated rat thymocytes. II. Independence of insulin and cyclic adenosine monophosphate. J. Biol. Chem. $247: 6927$

20. Robison, G. A., E. W. Sutherland, and R. W. Butcher. 1971. Cyclic AMP. Academic Press, Inc., New York. 146.

21. Carpenter, C. C. J., G. T. Curlin, and W. B. Greenough, III. 1969. Response of canine Thiry-Vella jejunal loops to cholera exotoxin and its modification by ethacrynic acid. J. Infect. Dis. 120: 332.

22. Al-Awqati, Q., W. B. Greenough, III, and C. C. J. Carpenter. 1969. Ethacrynic acid inhibits gut fluid loss in cholera. Clin. Res. 17: 422.

23. Serebro, H. A., F. L. Iber, J. H. Yardley, and T. R. Hendrix. 1969. Inhibition of cholera toxin action in the rabbit by cycloheximide. Gastroenterology. 56:506.

24. Harper, D. T., Jr., J. H. Yardley, and T. R. Hendrix. 1970. Reversal of cholera exotoxin-induced jejunal secretion by cycloheximide. Johns Hopkins Med. J. $126: 258$.

25. Grayer, D. T., H. A. Serebro, F. L. Iber, and T. R. Hendrix. 1970. Effect of cycloheximide on unidirectional sodium fluxes in the jejunum after cholera exotoxin exposure. Gastroenterology. 58: 815.

26. Finkelstein, R. A. 1970. Antitoxic immunity in experimental cholera: observations with purified antigens and the ligated ileal loop model. Infect. Immun. 1: 464.

27. Maimon, H. N., J. G. Banwell, and T. R. Hendrix.
1972. Inhibition of cholera toxin induced secretion. Clin. Res. 20: 459.

28. Katz, M. S., and W. B. Greenough, III. 1972. Selective inhibition of fat cell response to cholera toxin (CT) and epinephrine (E) by blocking agents. Clin. Res. $20: 531$.

29. Peterson, J. W., J. J. LoSpalluto, and R. A. Finkelstein. 1972. Localization of cholera toxin in vivo. J. Infect. Dis. 126: 617.

30. Hochstein, H. D., J. C. Feeley, and S. H. Richardson. 1970. Titration of cholera antitoxin levels by passive hemagglutination tests using fresh and formalinized sheep erythrocytes. Proc. Soc. Exp. Biol. Med. 133: 120.

31. Wolfe, S. M., and N. R. Shulman. 1969. Adenyl cyclase activity in human platelets. Biochem. Biophys. Res. Commun. $35: 265$.

32. Gardner, J. D., H. L. Klaeveman, J. P. Bilezikian, and G. D. Aurbach. 1973. Effect of $\beta$-adrenergic catecholamines on sodium transport in turkey erythrocytes. $J$. Biol. Chem. 248: 5590 .

33. Finkelstein, R. A., M. K. LaRue, and J. J. LoSpalluto. 1972. Properties of the cholera exo-enterotoxin: effects of dispersing agents and reducing agents in gel filtration and electrophoresis. Infect. Immun. 6: 934.

34. Bilezikian, J. P., and G. D. Aurbach. 1973. A $\beta$-adrenergic receptor of the turkey erythrocyte. I. Binding of catecholamine and relationship to adenylate cyclase activity. J. Biol. Chem. $248: 5577$.

35. Bilezikian, J. P., and G. D. Aurbach. 1973. A $\beta$-adrenergic receptor of the turkey erythrocyte. II. Characterization and solubilization of the receptor. J. Biol. Chem. 248: 5584 .

36. Birnbaumer, L., S. L. Poh1, M. Rodbell, and F. Sundby. 1972. The glucagon-sensitive adenylate cyclase system in plasma membranes of rat liver. VII. Hormonal stimulation: reversibility and dependence on concentration of free hormone. J. Biol. Chem. 247: 2038.

37. Kimberg, D. V., M. Field, E. Gershon, R. T. Schooley, and A. Henderson. 1973. Effects of cycloheximide on the response of intestinal mucosa to cholera enterotoxin. J. Clin. Invest. 52: 1376.

38. MacDonald, I. R., and R. J. Ellis. 1969. Does cycloheximide inhibit protein synthesis specifically in plant tissues? Nature (Lond.). 222: 791.

39. Evans, W. R. 1971. The effect of cycloheximide on membrane transport in Euglena. A comparative study with nigericin. J. Biol. Chem. 246: 6144.

40. Sandow, A. 1965. Excitation-contraction coupling in skeletal muscle. Pharmacol. Rev. 17: 265.

41. Cuatrecasas, P. 1973. Interaction of Vibrio cholerae enterotoxin with cell membranes. Biochemistry. 12: 3547.

42. Cuatrecasas, P. 1973. Gangliosides and membrane receptors for cholera toxin. Biochemistry. 12: 3558.

43. Cuatrecasas, P. 1973. Cholera toxin-fat cell interaction and the mechanism of activation of the lipolytic response. Biochemistry. $12: 3567$.

44. Cuatrecasas, P. 1973. Vibrio cholerae choleragenoid. Mechanism of inhibition of cholera toxin action. Biochemistry. 12 : 3577. 